\title{
Foundations of Immunology in Ayurvedic Classics
}

\author{
Ram H Singh*
}

(Received 13 October 2104; revised 24 December 2014)

\begin{abstract}
Immunology today is one of the fastest growing disciplines in Medicine and Biology. Its significance has grown more because of the growing significance of immune strength and resistance against different diseases besides the emergence of a wide range of immunological diseases. It is interesting to observe that the ancient Ayurvedic texts show a vivid description of the foundations of immunology thousands of years in the past. The Ayurvedic immunology is essentially a unique pro-nature holistic science with inherent bonds with nutritional status, genetic constitution and the aging process. Ayurveda describes the bio-factor ojas which is the quintessence of all the seven dhātus of the body and is responsible for the immune strength of an individual classically known as Ojabala and Vyädhiksamatva which refers to natural and acquired immunity. There are clear descriptions available in samhitās about the three broad categories of immune disorders, namely Oja-vyāpat, Oja-visramsa, and Oja-kșaya. The texts describe Rasāyana Tantra which is one of the eight branches of Astānga Ayurveda. Rasāyana remedies are known to sustain micro-nutrition and promote immune strength besides retarding the aging process. The present review critically examines the available literatures to evaluate the ancient concepts of early Ayurvedic Immunology in the light of recent developments.
\end{abstract}

Key words: Bala doṣa, Immunity, Immunology, Oja-Bala, Ojas, Prakrti, Rasāyana, Rejuvenation, Vyādhiksamatva

\section{INTRODUCTION}

Ayurveda is the oldest science of life and health care in the world, its antiquity going back to the ancient Vedas. Its classical ancient knowledge-base has survived up to the modern times through a set of six authentic ancient books consisting of three pre-Christian texts namely Caraka, Suśruta and Saṃhitās of Vāgbhaț̣a popularly known as Brhattraȳ besides three medieval texts namely Mādhavanidāna, Śārañgdharasaṃitā and Bhāvaprakāśa collectively called Laghuttray $\bar{\imath}$. These texts will reveal that Ayurveda has its own unique fundamental principles, its own biology, pathology, diagnostics, its own materia medica and principles of treatment which grant it the status of a full system of medicine.

There are three unique characteristic features of Ayurvedic medicine which provide it a distinction from conventional system of medicine. These features have now emerged as most relevant today in view of the changing paradigms of health-care systems and new knowledge-base. These features are: 1.The pronature approach, 2.The Holistic approach and 3. The personalized health-care strategy based on its fundamental prakrti-vikrti considerations. Ayurveda holds that our body-mind system has inherent power to tackle the causes of illness and to heal a disease spontaneously without any

\footnotetext{
* Distinguished Emeritus Professor, Department of Kayachikitsa, Faculty of Ayurveda, Institute of Medical Sciences, Banaras Hindu University, Varanasi, India. Email: rh_singh2001@yahoo.com
} 
artificial intervention. Ayurvedic physicians are directed by the śāstra to respect the Nature's effort of auto-healing and ordinarily not to use any unwanted intervention against the Nature's process. This is called the theory of svabhāvoparamavāda and the same is the pronature approach. Ayurveda considers the whole body-mind -spirit system as a single unit and so also it offers comprehensive holistic approach in management of a disease inclusive of diet, drug and total life style management. Such an integrative holistic approach is the basic nature of Ayurveda. Prakrti and Vikrti both are largely genetically determined processes and are to be tackled individually because no two individuals are similar hence Ayurveda advocates the principle of 'Purusam-purusam viksya' meaning there by an individualized health care. Ayurveda has certain major strengths which have contemporary relevance and may serve as potential leads for 'Reverse Innovation' and Translational Studies today. Among such strengths, Ayurgenomics and Immunology seem to be really promising. Let us discuss these issues briefly to understand how these are intermingled (Sharma, 1992, Udupa, 1980, Singh, 1995-2014).

\section{Ayurgenomics and Personalized Medicine}

Ayurveda identifies each individual being in terms of his genetically determined make-up classically known as prakrti in relation to the doctrine of tridosa and triguna. Deha-prakrti is the sum total of the physique, physiology and psychology of an individual and it literally denotes Genome as known today. This is the basis of the Ayurvedic concept of critically individualized approach in clinical medicine and therapeutics of Ayurveda. Such a prakrti is inherent and does not change in one life time although may be modified to some extent due to epigenetic factors such as life-style, environmental factors and dietetics. In Ayurvedic diagnostics a practitioner always attempts to label the prakrti of his patient before really making the vikrti diagnosis. The overall management of a patient is designed in relation to the tridoșic pattern of the prakrti and vikrti. This age-old concept of Ayurveda is being now globally accepted in the practice of conventional medicine too. It is now universally believed that all medicines are not effective in all individuals. There is a need of detailed pharmacogenomic studies in drug development as was advocated in Ayurveda thousands of years ago ${ }^{1-9}$. Similarly Ayurveda considers hereditary and genetic predisposition as the primary cause of many diseases, apathya and life-style errors being the other principal causes of illness. Thus our constitutional make-up, our health and our disease are essentially the product of our nature and our ecology i.e. our genome and epigenome intermingled intimately with each other (Diana 2012, Ghodke et al., 2011, Juyal et al., 2012, Mahalle et al., 2012, Rizzo-Sierra, 2011).

\section{IMMUNOLOGY TodAY}

Modern Immunology is a fast growing discipline in conventional biology and medicine. Besides its protective dimensions immunology is deeply involved in the etiopathogenesis of many major diseases. Immunological inflammation, immune degeneration of tissues and auto immune diseases are the hallmark of pathology today. Likewise immunologic knowledge has now been exploited in a big way as a tool to treat or to prevent certain diseases. Vaccines and immunization program have now brought in dramatic outcomes in certain areas of preventive community medicine as well as disease specific vaccines have shown new ways to treat difficult diseases. The emerging strength of anticancer vaccines is an example.

The immune system is a system of biological structures and processes within an organism that protects against disease by identifying and killing pathogens and tumor cells. It detects a wide variety of agents ranging from viruses to parasitic worms, and needs to 
distinguish them from the organism's own healthy cells and tissues in order to function properly. Detection is complicated as pathogens can evolve rapidly producing adaptations that avoid the immune system and allow the pathogen to successfully infect the host. To survive this challenge multiple mechanisms evolve that recognize and neutralize pathogens (Wikipedia).

Immunity is the central focus of modern immunology. Immunity is a biological term that describes a state of having sufficient biological defenses to avoid infection, disease or other unwanted biological invasion. Immunity involves both specific and nonspecific components. The nonspecific components act either as barriers or as eliminators of wide range of pathogens irrespective of antigenic specificity. Other components of the immune system adapt themselves to each new disease encountered and are able to generate pathogen-specific immunity. Ayurveda describes this defense function in a holistic manner under the terms ojabala and vyādhikṣamatva which will be explained in following paragraphs.

\section{FoundATIONS OF IMMUNOLOGY in Ayurveda}

The immune-compromised state of a victim i.e. depletion of vyādhiksamatva or resistance against disease is considered a major causative factor responsible for genesis of a disease. Vyādhiksamatva is involved in prevention of the occurrence of a new disease and it also retards the virulence and progression of a existing disease. Vyādhiksamatva in an individual is an attribute of his inherent ojas status or vital immune strength. The so designed defensive mechanism is the basis of Ayurvedic theory of 'svabhāvoparamavāda.' The Ayurvedic classics describe in detail the biology of ojas status and its disorders i.e. ojabala and baladoṣa.
The Ayurvedic texts describe a unique hitherto unknown concept of ojas i.e. vital essence of the body which is responsible for biological strength including the immune strength. Ojas is the final product of tissue nourishment and is the quintessence of all the seven dhātus namely rasa, rakta, māmsa, meda, asthi, majjā, śukra. Suśruta describes ojas as the paramateja of the saptadhatus and as the bala or biological strength of an individual. Ojas is considered to be of two kinds namely 1. parā ojas and 2. aparā ojas. Parā ojas is subtle in nature and is in minute quantity measuring only eight drops located in the heart while apara ojas is gross i.e. half an añjali in quantity spread all over the body. Parā ojas is a life factor and its injury and insult may lead to instantaneous death. Aparā ojas is responsible for gross biological and immune strength ${ }^{10-20}$.

\section{OJabala AND BaLAdoșa}

As stated above, ojas is the vital essence of our body present in the living body in varying amount and quality. Ojas is regularly formed in the body as the consequence of the digestion and tissue metabolism. This ojas material is the integral part of bodily cells and tissues. Qualitatively and quantitatively, of two kinds of ojas, parā ojas is the factor which sustains life while apara ojas is claimed to be responsible for the immune strength technically termed as oja bala. The oja bala derived from ojas has been categorized to be of three kinds viz 1. Sahaja bala or primary natural bio-strength and immunity, 2. Kālaja bala or acquired immunity through environmental factors such as age, climate etc and 3. Yuktikrta bala or the artificially induced acquired bio-strength and immunity ${ }^{11,12}$. The classics prompt to utilize these three resources to enhance the bala/immunity in order to prevent all ailments especially chronic wasting disorders and contagious diseases, such as Śoșa, Kșaya and Yakșmāi.e. Pthisis and Tuberculosis etc. 
There are three categories of Bala dosa or disorders of bala which are comparable to three categories of immune disorders such as 1.Ojavyāpat (immune-aberrations and allergies), 2.Ojavisramsa (dislodged immunity and autoimmune disorders) and 3. Oja-kșaya (immunodeficiency) ${ }^{13-}$ ${ }^{18}$. As the basic nature of these three categories of baladosa are specifically different there has to be different approaches to their diagnosis and treatment. In case of oja-vyāpat there is a need to curve the excessive immune response therapeutically. In case of oja-visramsa where immune strength is dislodged there is a need to plan samśodhana to cleanse the channels so that the ojas is restored back to its normal site. In case of oja-kșaya where there is clear immunodeficiency a wise physician should administer rasāyana remedies and good nutrition to replenish the ojas system leading in turn further to improved ojabala. Enhancing bala which includes immune potency by adherence to a code of conduct including appropriate diet, physical activity and positive life-style is the core of svasthavritta in Ayurveda. Rasāyana therapy which is an important biological aid to enhance bala i.e. immunity will be discussed later in this review.

It cannot be overemphasized that while looking at the above mentioned ancient classical descriptions on ojabala and bala doșa it seems immunology was already highly advanced in samhita period of Ayurveda and the knowledge in this field was almost comparable with the latest basic knowledge of immunology as known today although now the technological advances in this field have been outstanding. However it should be kept in mind that the scientists who made the new discoveries in germ theory, modern immunology, microbiome etc were unaware of Ayurveda and did their work independently. The author of this review is inclined to suggest that these modern discoveries could have been easier and faster if the modern scientists could have known the pre-existing knowledge of Ayurveda in the respective field. Reverse innovation is always less time consuming and easier because of the pre-existing leads available at hand.

\section{IMMUNe disoRders in SOME MAJOR Diseases}

All the three classics of Ayurveda propound the doctrine of immune-compromised state as the precursor of chronic wasting diseases like Phthisis and Tuberculosis i.e. śoșa, kșaya and yaksmā. Suśruta while describing the samkrāmaka or contagious diseases specially mentions jvara or fevers, sosa or phthisis and yaksmā or tuberculosis, abhisyanda or conjunctivitis and kuștha or dermatoses such as leprosy emphasizing that these diseases spread from person to person by contact. The spread of such diseases may be prevented by avoiding personal contacts and by promoting inner vyādhiksamatva or immunity with the help of healthy life style, good nutrition and rasāyana therapy described in Ayurveda.

Besides, the Ayurvedic texts also refer to the significance of immune factors in certain diseases showing indirect evidence. Diabetes mellitus is vividly described in all Ayurvedic classics in terms of madhumeha which is one of the 20 types of Prameha. Ayurvedic disease entities are described as the outcome of interaction between dosas and the dusyas and the actual diagnosis and prognosis of the disease depend on the doșa-dusya combination. Prameha has maximum number of dusyas indicating that it is a disease involving the whole body and as such it is difficult to cure. Interestingly ojas, which is the sheet anchor of the immune system of the body, is also counted among the dusyas i.e. morbid factors of Prameha. It means that Ayurveda considers Diabetes as a disease involving the immune system. This factor is now being scientifically proved. Similarly āmavāta, a disease which is similar to rheumatoid arthritis is described to be caused by impact of a systemic antigenic material 
called $\bar{a} m a$ which is a byproduct of faulty digestion and metabolism. Incidentally now a days rheumatoid arthritis is known as an auto immune disease which is an example of oja-visramsa as described earlier. There are also descriptions available to suggest that immunity is intimately linked with mind, indicative of the concept of psychoneuroimmunology in Ayurveda.

\section{Ancient Ayurvedic Leads in Microbiology}

It will be pertinent to overview the concept of microbiology and parasitology in Ayurvedic classics in the context of the immunity and body resistance as described in Ayurveda in reference to ojas, bala and vyādhikșamatva. Though microbes and their role in pathology was not known in modern medicine before 200 years from now, Ayurveda had a good knowledge about their entity. However the knowledge was of a primitive nature. Ayurveda describes two kinds of organisms namely 1. Prākrta or nonpathogenic, 2. Vaikrta or pathogenic. They also described two categories of pathogens/parasites namely 1. External, 2.Internal. The internal organisms were claimed to be mainly of three categories in terms of their thriving milieu viz. 1 . Those sustaining on mucus, 2. Those growing over fecal matter 3 . Those growing in blood. Some of them particularly those thriving on fecal matter seem to be intestinal parasites while others simulate microbes. The texts repeatedly advocate to protect surgical wounds from these organisms. There is also a clear description about the vector borne nature of some organisms and the texts consider certain diseases such as leprosy, tuberculosis, conjunctivitis and fever as contagious diseases which spread by contact with other patients suffering from the same disease.

It is amazing that these ancient texts recognized the existence of friendly nonpathogenic organisms and their function which is now considered a great discovery in microbiology. It is claimed by modern scientists that our living body is made up of 10 trillion somatic cells and our body of 10 trillion cells provide habitat for 100 trillion friendly microbes. This empire of microbes is called Microbiome which is gradually gaining the importance almost parallel to the Genome/Epigenome phenomenon. This microbiome is like an organized organ with unique functions and hence need to be protected in the same way as we protect our other vital organs like liver, heart or kidney etc. This recognition of the existence of these friendly prākrta nonpathogenic organisms by Ayurveda thousands of years ago is of great historical significance ${ }^{21-23}$.

\section{Promoting Ojas-status and VYĀDHIKȘAMATVA}

In view of the immune status of an individual being an important factor for conservation of health and prevention of disease, Ayurveda deliberates extensively on positive health measures such as life-style management, healthy dietetics and rejuvenation therapy with the help of a range of micro-medicinal nutrients called rasāyana. A rasāyana remedy promotes nutritional status of an individual through qualitative changes in bodily cells and tissue leading in turn to improved bodily function, promotion of health and prevention of disease as well as longevity. These rasāyanas are considered the therapeutic means of obtaining the best quality of dhātus through micro-nutrition dynamics. It is believed that a rasāyana acts at one or all of the following levels namely: 1 . At the level of rasa directly enriching the nutritional value of plasma. Such rasāyanas are essentially nutrients in themselves. 2. At the level of agni some rasāyanas such as pippalī and sunthī work as digestive and metabolic boosters and lead in turn to improved nutritional status. 3. At the level of srotas some rasāyanas like guggulu and harìtakī promote systemic nutrition by way of sroto-prasādana or 
as promoters of micro-circulation and tissue perfusion. All such situations promote nutritional status of an individual with improved quality of cells and tissues in the body, longevity, immunity and superior health both physical and mental. In this entire process ojas is the basic matrix and all rasāyanas are supposed to be oja-vardhaka remedies. Rasāyana tantra was developed as one of the eight branches of Aștāinga Ayurveda which is comparable to nutrition science, immunology and geriatrics all interlinked together. Thus ayurvedic immunology is a continuum of vital nutrition $^{24-30}$.

\section{Dhātu-Posana, Dhätusātra and OJas}

Ayurvedic biology swings around the holistic continuum of nutrition, agni or metabolic fire, specific sequence of formation of seven primordial tissues of the body termed as sapta dhātus - rasa, rakta, māmsa, meda, asthi, majjā, sukra leading at the apex to the formation ojas which is the vital essence of all the seven dhätus that constitutes the vital strength and immune defense of the living body. Each dhātu has its sāra i.e. quality index which denotes the quality of the respective $d h \bar{a} t u$. The sequence of events taking place in this process are depicted below.

$\bar{A} h \bar{a} r a+$ Agni+Intact srotas system $=\bar{A} h \bar{a} r a$ rasa = tissue nourishment and new tissue formation:

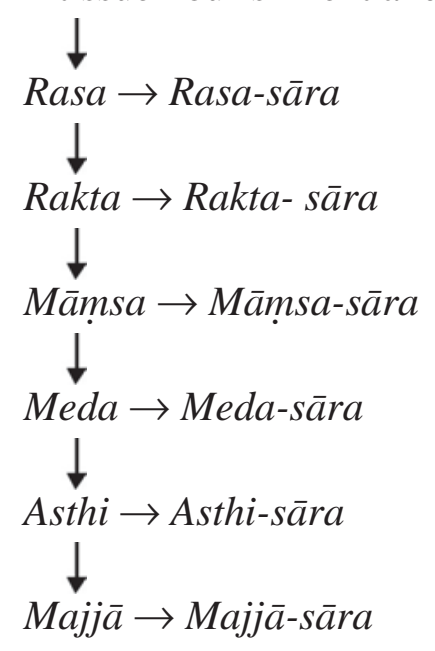

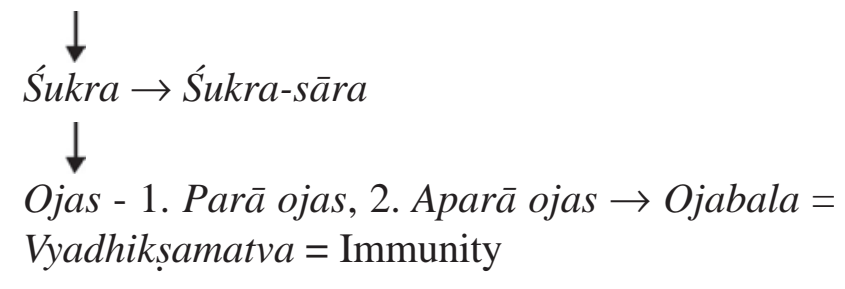

\section{RasĀyana Therapy and RejuVEnAtion}

Ayurveda even during the classical age was a fairly developed medical and health science. It had eight specialty branches, hence Ayurveda is called Aștāinga ayurveda even today. The eight classical branches of Ayurveda are 1. Kāyacikitsā (Internal Medicine), 2. Śalya tantra (Surgery), 3. Śālākya tantra (ENT and Ophthalmology), 4. Kaumārabhrtya (Pediatrics and Gynecology), 5. Rasāyan tantra (Immunology and Geriatrics), 6. Bājikarana tantra (Sexology and Reproduction), 7. Agada tantra (Toxicology) and 8. Bhūtavidyā (Psychiatry and Demonology). Out of these eight branches, Rasāyana tantra is the branch which deals with immunology and geriatrics.

The term rasāyana (rasa+ayana) essentially refers to acquisition, movement or circulation of nutrition needed to provide nourishment to the bodily cells and tissue. This phenomenon is considered conducive to the promotion of the qualities of dhātus i.e. bodily cells and tissues. The improved nutritional status and the better qualities of dhätus lead in turn to a series of secondary attributes of rasāyana such as longevity, immunity, improved mental and intellectual competence. As stated above it is presumed that the rasāyana agents promote nutrition through one or all of the three modes at the level of rasa, agni and srota, meaning there by that some rasāyanas are nutrients in themselves, while certain others are metabolic boosters and some others are the agents which cleanse the micro-channels and augment microcirculation of nutrients in the body, the net result of all the three being the improved nutritional status. Thus Ayurvedic immunology 


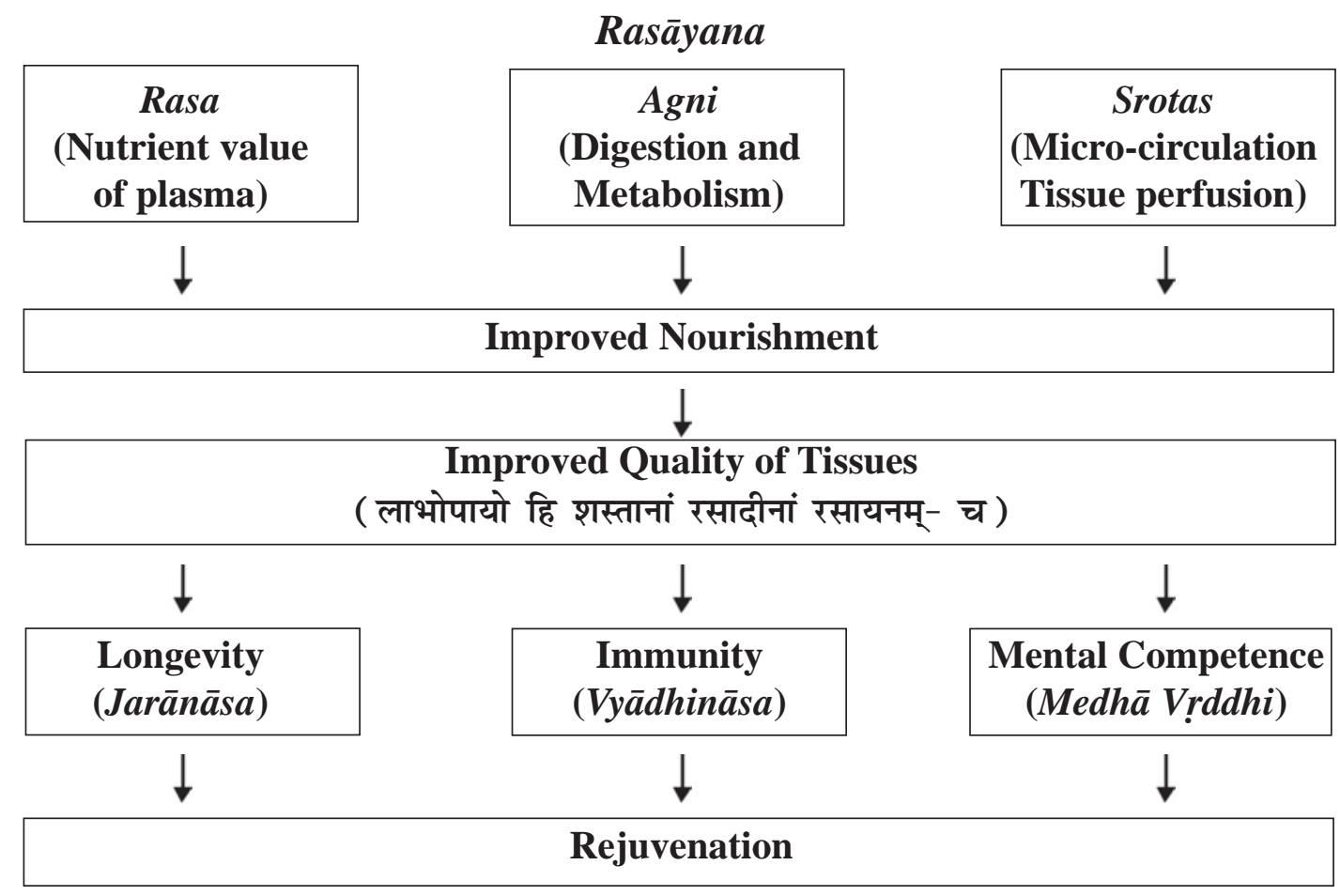

conceives a bond between micro nutrition with immune enhancing effect because according to Ayurveda ojas is the basic matrix of immune system and ojas is the supreme outcome of the process of nourishment in the living body. Thus nutrition, microcirculation and immunity are intimately linked. This is the concept of Holistic Ayurvedic Immunology. Hence Ayurveda advocates for better nutrition, richer ojas system, stronger agni and competent microcirculation in order to have good immune strength. Ayurveda does not separate the immune strength from the total bio-strength.

\section{Classifying Rasāyana Remedies}

Classically the Rasāyana remedies and therapy procedures are categorized as below;

1. In terms of the scope of use rasāyanas are of two kinds - a) Kāmya rasāyanas which are used in apparently healthy individuals for the purpose of positive health care. Such rasāyanas again may be of three kinds namely 1. Srikāmya rasāyanas which are supposed to promote lusture of the physical body, 2 . Prānakāmya rasāyanas which are used to achieve healthy longevity, 3. Medhākāmya rasāyanas which are claimed to be specific for promotion of mental health and cognitive ability. b) Naimittika rasāyanas which are used in diseased individuals for the purpose of imparting defensive power in a patient to be able to fight with the existing disease. They are supposed to be disease specific rasāyanas. The classical examples given in the classical texts are the use of Silājatu rasāyana for patients of Diabetes mellitus and Tubarak Rasāyana for the patients of Leprosy.

2. In terms of the procedures to be adopted in administration of rasāyana therapy the procedures are of two kinds, namely a) Vātatāpika rasāyana therapy which is used outdoor without adopting any kind of intensive regimen, b) Kutīprāveśika rasāyana procedure where the patient is placed under an intensive regimen admitting the patient in a specially designed trigarbhā rasāyana kuțī or therapy 
chamber where he first undergoes pañcakarma therapy to cleanse bodily channels and then he consumes the rasāyana remedy chosen for him in consideration of his age, his prakrti, the climate, weather and many other influencing factors. The patient remains on therapeutic diet and prescribed life style for the prescribed duration of time. This intensive rasāyana therapy is believed to rejuvenate the body-mind system of the patient described as Rejuvenation or Kāyākalpa.

3. In terms of the therapeutic modalities, the rasāyana therapy has been described to be of three kinds namely a) Ācāra rasāyana which is essentially an adravyabhūta non-medicinal positive life style regimen and it is claimed that the prescribed positive life itself may produce all the expected benefits of rasāyana therapy. b) Ājasrik rasāyana which is nothing but a rasāyana like dietetics. This too is a nonmedicinal procedure and it is administered in the form of rejuvenating food and dietetics. c) Aușadhi rasāyana where a range of herbomineral rasāyana drugs are used to achieve the rasāyana effect in the body. These are medicinal rasāyanas which produce rasāyana effect through their actions at one or all of the three levels mentioned above such as at the level of rasa, agni and srotas i.e. as micronutrients, metabolic boosters or as promoters of microcirculation.

4. Ancient texts specially Suśruta Samhitā describes a group of special rasāyanas called divya rasāyana with a claim that if appropriately consumed the divya rasāyanas transform the body mind system with outstanding achievements of divine nature. Suśruta Cikitsā sthāna chapter 30 describes 18 rare great herbs namely ajagari, svetkapott, kriṣnakapoți, gonasi, vārahi, kanyā, catrā, aticchatrā, karenu, aja, cakrakā, àdityaparn̄ī, brahmasuvarcalā, sravaṇi, mahāsravaṇi, golomī, ajalomī and mahāvegavatī. These are
18 great herbs like soma. The procedures, benediction and prayer in their respect are like Soma as prescribed in the scripture. Probably it was the Soma herbs of Ayurveda which were used to prepare the somarasa that the gods used in ancient times for their health and longevity. Unfortunately these unique herbs which were prescribed for gods are now not available and their identity is lost. There is a need of research on these great remedies.

\section{Accumulating New Evidence}

Any review of the new evidence-base is beyond the scope of this article. However the author is inclined to add a passing reference to the trend of raising new evidence to validate the ancient wisdom. There has not been any attempt to investigate the science behind the Ayurvedic concepts and theories but there has been lot of interest among the biomedical scientists to evaluate the therapeutic value of a range of rasāyana remedies of Ayurveda specially for their immuno-enhancing, neuro-nutrient, anti-aging and anti-stress effect showing encouraging results. Among the glimpses of such studies the pertinent ones seem to be the following. Kobayama et al. (2005) reported their invitro studies in British Journal of Pharmacology demonstrating the efficacy of Withanolide-A isolated from rasāyana drug aśvagandhā (Withenia somnifera dunal.) as a neuro-regenerative agent. Neurons cultured with Withanolide-A showed that the dendrites of the neurons became elongated and the synopses got reconstructed. Aśvagandhā was also shown to reduce the biological aging scores in elderly volunteers kept on aśvagandhä rasāyana for six months as reported by Dwivedi and Singh (1997). Similarly laboratory studies reported in Journal of Ethnopharmacology by Archana and Namasivayam (1999) showed significant antistress effect. Singh et al. (2008) reported in Biogerontology their studies on the neuro-nutrient effect of Ayurvedic rasāyanas in brain aging. So 
also Jayaprakash et al. (2013) reported neuroprotective role of aśvagandhā in mouse model of Parkinsonism. This drug is already reported to possess immuno modulating effect. It is suggested that neuro-nutrient effect, neuro-protective impact, anti-stress effect, anti-aging effect and immunemodulater effects are interlinked and are likely to be a continuum. Some rasāyana drugs specially āmalakī rasāyana have been reported by investigators like Lakhotia and associates to produce significant beneficial effect on life process including DNA repair in experimental models.

Rasāyanas like āmalakī have been suggested to be used to maximize the anticancer immunity in cancer patients undergoing artificial immunotherapy using a range of anticancer vaccines. Although till date no data is available to evaluate any success potential. These rasāyanas have also been used with benefit to protect the patients undergoing chemo therapy and radiation therapy from harmful effects of these therapies. Rasāyana drugs like $\bar{a}$ malaki and haridrā were recently used in treatment of mild to moderate diabetes mellitus with evidence of immunocompromised state and three months treatment showed noticeable improvement in the rate of gycemic control of these patients along with improved ojas status measured by a rating scale for negative ojas scores. A preliminary clinical study conducted by Singh and associates in cases of Bronchial Asthma with vaman therapy i.e. therapeutic emesis, indicated significant evidence of Histamine dialysis and suggested Mast cell stabilizing effect associated with significant symptomatic relief and prolonged remission of the disease. It cannot be overemphasized that the public demand for new scientific evidence for safety and accuracy of traditional medicine are increasing and such a challenge needs to be adequately addressed (Rastogi et al. 2012).

\section{Conclusion}

Thus the ancient Ayurvedic texts have described the basics of a unique holistic immunology interlinked with tissue nourishment, ojas formation as the biological determinant of vital bio-strength and immune strength in an individual. Ayurvedic immunology is not merely limited to antigen antibody phenomenon in infective diseases and immune-degeneration rather it is involved in maintenance of positive health in general including homoeostasis, resistance against disease, longevity and stress tolerance with an inherent bond with the nutritional status of an individual. The texts present a very comprehensive account of the Ayurvedic science of nutrition, longevity, immunity against disease and stress coping ability, all in one sweep in its Rasāyana Tantra which is one of the eight major specialties of Aștāinga Ayurveda. Thus Ayurvedic immunology has strong potential to enrich the contemporary immunology with its pro-nature individualized holistic approach which is very much missing in modern immunology with dominant pathological face and limitations of its reductionist approach.

\section{Selected Textual References}

1. शुक्र शोणित संयोगे यो भवेद्दोष उत्कटः प्रकृतिर्जायते तेन। - सु.शा. 4:63

The Dosa (vata, pitta or kapha) which is expressed with dominance during fertilization ie contact of sperm and ovum in a couple manifests the Prakrti or Genetic Constitution of the particular offspring. - SS.S $\bar{a} .4 .63$

2. दोषानुशयिता हि एषां देह प्रकृति उच्यते। - च.सू. $7: 40$ The Doșa specific constitution is called Deha Prakrti.CS.Su.7.40

3. प्रकृतिर्नाम जन्ममरणान्तराल भाविनी गर्भावक्रान्ति काले स्वकारणोद्रेक जनिता निर्विकार कारणीस्थितिः। रसवेशेषिक / नरसिंह भाष्य

The Prakrti is the product of the dominant manifestation of the respective humors during embryogenesis occurring in the period falling between birth and death.- $R V /$ Narasimha bhāṣya.

4. कायानां प्रकृतिर्जात्वा स्वरूपां क्रियां चरेत्। - सु.शा. 4:96 
A practicing physician should plan the line of disease management after duly determining the Prakrti/ constitution of the individual. SS. Śā.4.96.

महाप्रकृतयस्त्वेता। रजःसत्त्वतमः कृताः। - सु.शा. 4:95

The Mental Constitution is created by the relative preponderance of the three gunas viz. sattva,raja and tama and is called Mahaprakrti. SS. Śă.4.95.

5. शुक्रशोणितप्रकृतिं कालगर्भाशय प्रकृतिं मातुराहार विहार प्रकृतिं महाभूत विकार प्रकृतिं च गर्भशरीरमपेक्षते। - च.वि. 8:97

The pre-birth constitution of an individual is relative to the embryonic conditions. - CS.Vi.8.97.

6. तत्र प्रकृतिर्जातिप्रसक्ता च, कुलप्रसक्ता च, देशानुपातिनी च, कालानुपातिनी च, वयोऽनुपातिनी च, प्रत्यात्मनियता चेति। - च.इ. 1: 6

The Prakrti is also re-shaped by epigenetic factors like caste, family, climate, chronology, age etc. CS. In 1:6

7. दौहृदविमानात् कुज्जं कुणिं खज्जं जड़ं वामनं विकृताक्षमनक्षं वा नारी सुतं जनयति।

- सु.शा. 3:18

Gestational errors may lead to birth of a child with a variety of genetic defects such as autism, deformed body, lame, dwarfism, visual errors and blindness etc. - SS. Śā. 3.18

8. सत्ववैशेष्य कराणि पुनस्तेषां तेषां प्राणिनां मातृपितृ सत्वान्यन्तर्वल्याः श्रुतयश्चाभिक्षणं स्वोचितं च कर्म सत्वविशेषाभ्यौसथचेति। - च.शा. 8:17

The mental features of a new born carries the mental traits of the respective parents. The religious pursuits of a pregnant woman leave similar impacts on her offspring. - CS. Śā. 8.17

9. तस्मादातुरं परीक्षेत् प्रकृतितश्च विकृतितथच, सारतश्च, सहननतथच, प्रमाणतश्च, सात्म्यतश्च, सत्त्वतश्च, आहारशक्तितश्च, व्यायामशक्तितश्च, वयस्तश्चेति वलप्रमाण विशेष ग्रहण हेतोः। - च.वि. 8:96

A physician should examine the patient for his Prakrti or genetic constitution, morbidity, qualities of his bodily cells and tissues, body build, anthropometry, his digestive power, his exercise endurance and his rate of aging. CS.Vi.8.96

कायानां प्रकृतिर्जात्वा स्वरूपां क्रिया चरेत्। - सु.शा. 4:96 Physician should treat the patient after knowing his Prakrti. SS. Śa.4.95

पुरुषं पुरुषं वीक्ष्य स ज्ञेयो भिषगुत्तमः। - च.सू. 1:123
A wise physician considers each patient as unique and plans carefully individualized therapeutic intervention (keeping in view the Prakrti which denotes individual Genome). - CS.Sū.1.123

10. तत्र रसादीनां शुक्रान्तानां यत परंतेजः तत् खल्वोजस्तदेव बलमिति उच्यते। - सु.सू. 15:19

Superior most quint essence of the seven primordial tissues of the body is called ojas and the same is ones bala or biological strength which includes his immune strength too. - SS.Sū.15.19.

11. त्रिविधं बलमिति - सहजं कालजं युक्तिकृतं च। सहजं यच्छरीरसत्वयो: प्राकृतं कालकृतमृतु विभागजंवियः कृत च, युक्तिकृतं पुनस्तद्यदाहार चेष्टा योगजम्। - च.सू. 11:36

The biological strength/immune strength of an individual may be of three kinds, viz. (1) Primary natural strength, (2) naturally occurring acquired strength/immunity produced by impact of chronobiology, and (3) Artificially induced acquired biostrength/immunity. - CS.Sū.11.36.

12. तत्र बलेन स्थिरोपचितमांसता सर्वचेष्टा स्वप्रतिघातः स्वरवर्ण प्रसादो। वाह्याभ्यन्तराणां च करणानामात्मकार्य प्रतिपत्तिर्भवति। ।

- सु.सू. 15:25

Bala (positive Bio/immuno-strength imparts stable well built muscles, un-interrupted bodily functions, good complexion and voice, smooth functioning of the motor and sensory organs. - SS.Sü.15.25.

13. त्रयदोषा बलस्योक्ता व्यापद् विस्त्रंसन क्षयाः।-सु.सू. 15:25

There are three kinds of immune disorders, viz.1. Ojavyapat or aberrant/labile immune disorder, 2.Ojavisransa or dislodged immunity such as autoimmune disorder, and 3.Oja-kṣaya (Immune deficiency). SS.Sū.15.25

14. विस्त्रंसः स्थानात च्युतिरिमिधातादिमिरेव। - सु.सू. 1:24 पर डल्हण

Oja visransa is dislodged immune strength caused by trauma etc. such as seen in cases of autoimmune diseases. - SS.Sū.1.24. Dalhana commentary.

15. व्यापद अन्यथापत्तिः सा दुष्टदोषदुष्यसंसर्गात्। - सु.सू. 15: 24

Ojavyāpat is aberrant immune function which is brought about by morbid Doṣa-Dușya interaction. SS. Sū. 15.24

16. क्षयः स्व प्रमाणात् शोकध्यानक्षयादिमि: - सु.सू. 15

Ojaksoya refers to immune deficiency. - SS. Sū. 15 
17. अभिघातात्क्षयात्कोपाच्छोकाद्धयनाच्छ्रमात्क्षुधः।

Trauma, emaciation, anger, sorrow and excessive physical exertion result into ojaksaya, i.e. immune compromised state.

18. ओजः सङक्षीयते हयोभ्यो धातुग्रहणानिःसृतम्।। - सु.सू. 15: 24

The above factors deplete immune strength. $-S S$. Sū. 15.24

19. व्याधिक्षमित्वं व्याधिबलविरोधित्वं व्याध्युत्पादप्रतिबन्धकत्वमिति यावत्। - च.सू. 28:16 पर चक्रपाणि

Immune strength prevents a disease on one hand and also reduces the severity of an existing disease on the other hand. - CS. Sū. 28.16/Chakra Commentary.

20. न च सर्वाणि शरीराणि व्याधिक्षमत्वे समर्थानि भवन्ति। च.सू. 28:16

All individuals are not equally and always empowered with immunity. - CS. Sū. 28.16

21. विंशतिविधा: कृमयः पुनर्मुदृष्टा नानाविधेन प्रविभागेनान्यत्र। सहजेम्यः ते पुनः प्रकृतिभिर्भिद्यमाना श्च तुर्विधा भवन्ति; तद्यथा -पुरीषजा: श्लेष्मजा:, शोणितजा, मलजाथचेति। - च.वि. 7:9

The parasites and Microbes are of 20 categories further categorized as many subtypes in terms of their habitat. The parasites/microbes are of four kinds, viz. fecal, mucus, blood borne and those thriving on external impurities. - CS. Vi. 7.9

22. तत्र सर्वक्रिमीणामपकर्षणमेवादितः कार्यं, ततः प्रकृति विधातः अनन्तरं निदानोक्तानां भावानामनुपसेवनमिति। - च.वि. 7:14

The parasites are treated by physical removal, by elimination of the causes and by therapeutic rendering of the pathogens from pathogenic to nonpathogenic nature. CS. Vi. 7.14

23. प्रसंगात् गात्र संस्पर्शानि:श्वासात् सहभोजनात्।

सहशय्यासनाच्चापि गंधमाल्यानुलेपनात्।।

कुष्ठ ज्वरथच शोषथच नेत्रामिष्यन्द एव च। औपसर्गिकरोगांथच संक्रमन्ति नरान्नरम्। - सु.नि. 5: 32-33

Dermatoses, fevers, tuberculosis and conjunctivitis spread from person to person by physical contact through sexual contact, touching the body, inhalation, eating together, sleeping with same bed, sitting together by apply/using contaminated flowers, garlands, sharing perfumes etc. - SS. Ni. 5.32-33

24. भेषजं द्विविधं च तत्। स्वस्थस्योर्जस्करं किज्चित् किग्चिदार्तस्य रोगनुत्। - च.चि. 1/1:4
Medicines are of two kinds: (1) Those which enrich vigor and vitality in the healthy, and (2) Those which remove the diseases from the diseased persons. $-C S$. Ci. $1 / 1.4$

25. स्वस्थस्योर्जस्करं यत्तु (तद्वृष्यं) तद्रसायनम्। - च.चि. 1/ $1: 5$

The remedies which impart health and vigor are categorized as Brisya (viriliser) and Rasāyana (rejuvenatives). - CS. Ci. 1/1.5

26. रसायनतन्त्रं नाम वयःस्थापनमायुमेधावलकरं रोगापहरण समर्थं च। - सु.सू. $1: 7$

The science of rasāyana (medicinal rejuvenation) imparts longevity, cognitive ability, biological strength and removes diseases. - SS. Su. 1.7

रसायनं तज्ञेयं यज्जराव्याधिनाशनम्। - शा.सं.पूर्व 4:13

The remedies which alleviate senescence and disease are called rasāyana. - Sh. S. Purva 4.13

27. दीर्घमायुः स्मृतिर्मेधामारोग्यं तरुणं वयः। प्रभावर्ण स्वरौदार्यं देहेन्द्रियवलोदयम्।।

वाक्सिद्धि वृषतां कान्तिमाप्नोति रसायनात्। लाभोपायोहि शस्तानां रसादीनां रक्षायनम्।। - अ.ह्..उ. 39:1,2

The rasāyana remedies promote longevity, memory, cognitive ability, health, youth, lustier, complexion, healthy voice, gesture, sensorial and somatic strength, perfection, in speech, virility, shining face. The rasāyana is the means of procuring the superior tissues. - As. Hr. Utta. 39.1,2

28. लाभोपायो हि शस्तानां रसादीनां रसायनम्। - च.चि. 1/1:8 The rasāyanas are the means of procuring the best quality of cells and tissues of the body. - CS. Ci. 1/1.8

29. मेध्यानि चैतानि रसायनानि मेध्याविशेषेण च शंखपुष्पी।।

- च.चि. 1/3:30-31

Sankhapuspi (Convolvus pluricaulis) is the best among the Medhya rasāyanas (neuronutrients/nervine tonics). - CS. Ci. 1/3.30-31

30. वाल्यं वृद्धिश्छविर्मेधा त्वग्दृष्टि शुक्रविक्रमौ।

बुद्धि: कर्मेन्द्रियं चेतो जीविंतदशतो हसेत।।

- शा.स.पू. 6:20

The normal aging process proceeds from first decade to 12th decade of ones like marked with sequential decade-wise biolosses, viz. (1) Corpulence, (2) Growth, (3) Lustier, (4) Intellect, (5) Skin texture, (6) Vision, (7) Virility, (8) Physical strength, (9) Cognitive ability, (10) Locomotor function, (11) Consciousness and (12) the Life. - Sh. S. Purva 6.20 


\section{BiBLIOGRAPHY}

Archana, R. and Namshivayam, A. Antistress effect of Withania somnifera Dunal, J. Ethnopharmacology. 64:91-93, 1999

Caraka 700 BC CS. Ci. Ch. 1, pada 1-4. Edited by Sharma, PV, Choukhaba Orientalia, Varanasi, India 2002

Caraka 700BC, CS. Sū. Ch. 1 Edited by Sharma PV, Choukhamba Orientalia, Varanasi, India 2002

Diana I Lurie, Ayurveda and Pharmacogenomics, Guest Editorial Annals of Ayurvedic Medicine 1.4(2012): 126.

Dwivedi, KK and Singh, RH. A study on the psychiatric symptoms in in geriatric patients and response of Ayurvedic Rasayana therapy. Ph.D. thesis, Kayacikitsa, BHU 1997.

Ghodke, Y., Joshi, K and Patwardhan, B. Traditional medicine to modern pharmacogenomics Ayurveda Prakriti types and CYP2C19 Gene polymorphism associated with the metabolic variability. Evidence based Complementary Alternative Medicine, P 249528, 2011

Juyal, RC et al. Potential of Ayurgenomics approach in complex trait research: leads from a pilot study on Rheumatoid arthritis. PLoSONE.2012,7/9;Pc45752

Jayprakash et al. Neuroprotective role of Withania somnifera root extract in mouse model of Parkinsonism. Neurochem. Res.Feb.27,2013

Kobayama, T.et al. Nutritic regeneration and synoptic reconstruction induced by Withanolide-A . British J.Pharmacol.144/7:961-971,2005

Mādhava Kara 900 AD Madhava Nidāna, edited by Upadhyaya,YN Choukhamba publication, Varanasi/Delhi, India

Mahalle, NP et al. Association of constitutional types of Ayurveda with cardiovascular risk factors, inflammatory markers and Insulin resistance. J. Ayurveda and Integrative Medicine.2012,3/3.p, 157.

Rastogi, S, Chiappelli, F. and Singh, RH. Evidence based practice of complementary alternative medicine. Special monograph. Springer publication, Germany , 2012 pp 1-250

Rizzo-Sierra, CV. Ayurvedic genomics, constitutional psychology and endocrinology: The missing connection. J. Alternat.Complement.Med.17.5(2011): 465-8.
Sarangdhara 1300AD, Sarandhara samhita Choukhamba publications Varanasi/Delhi, India

Sharma, PV. History of Medicine in India. Published by Indian National Science Academy, New Delhi, India, 1992

Singh, RH. Integrative Medicine, Choukhamba surbharati publications Varanasi/Delhi, India 2009

Singh, RH and associates. Advances in Ayurvedic medicine, Research monographs in Five volumes. Choukhamba Vishwa Bharati, Varanasi, India, 2005

Singh, RH and Rastogi, S. Rasayana Therapy and Rejuvenation. In Evidence based practice of CAM Springer, Germany. 2012, PP. 177-190.

Singh, RH. The science behind the concept of Ojas, Ojabala and Vyadhiksamattva. Editorial in Abhinava Dhanvantari vol.1 No.I (2014): 17-20

Singh, RH. Kayachikitsa vol. I-II, Choukhamba Surbharati Prakashan, Varanasi/Delhi 2005

Singh, RH. Narsimhamurthy, K. and Singh, Girish. Neuronutrient impact of Ayurvedic Rasayan therapy in brain aging, Biogerontology, 9 (2008):360-374

Singh, RH. Basic Tenets of Ayurvedic Dietetics and Nutrition. in special monograph Ayurvedic Food Science, Springer USA, 2014.

Singh, RH. Ayurvediya Samsodhana Chikitsa, the newer dimensions. Journal of Visva Ayurveda Parisad

Singh, RH. The holistic principles of Ayurvedic medicine. Choukhamba surbharati prakashan, Varanasi/ Delhi 1995

Suśruta 600 BC, SS. Sū chaps. 4, 15, 21 edited by Singhal et.al. Choukhamba Surbharati 2nd edition Varanasi/ Delhi, India, 2002

Suśruta 600BC, SS Ci Chap. 27-30 edited by Singhal et al Choukhamba Surbharati $2^{\text {nd }}$ edition Varanasi/Delhi, India 2002

Udupa, KN and Singh, RH. Science and philosophy of Indian medicine. Baidyanath Ayurveda Bhawan Nagpur, India 1980

Vāgbhațta 300 AD Aștāinga Samgraha, Choukhamba publications Varanasi/Delhi, India

Vāgbhatta 300AD, Asțāinga Hrdaya Uttara tantra, Chapter 39 Rasāyana cikitsa Choukhamba publications Varanasi, India

wikipedia.org/wiki/Immunity_(medical) August 13, 2014 